\title{
Degradation of 2,4-dichlorophenoxyacetic acid by haloalkaliphilic bacteria
}

Center for Microbial Ecology and Department of Microbiology, Michigan State University, East Lansing, Michigan 48824, USA

\author{
Olga Maltseva, Catherine McGowan, Roberta Fulthorpe $\dagger$ \\ and Patrick Oriel \\ Author for correspondence: Olga Maltseva. Tel: +1 517353 7858. Fax: +1 5173532917. \\ e-mail:23142ovm@msu.edu
}

Three 2,4-dichlorophenoxyacetic acid (2,4-D)-degrading bacterial isolates were obtained from the highly saline and alkaline Alkali Lake site in southwestern Oregon contaminated with 2,4-D production wastes. While similar in most respects, the three isolates differed significantly in 2,4-D degradation rates, with the most active strain, I-18, demonstrating an ability to degrade up to

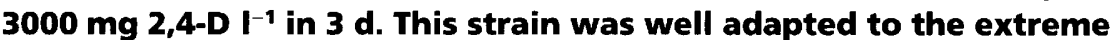
environment from which it was isolated, growing optimally on 2,4-D at pH 8.4-9.4 and at sodium ion concentrations of 0.6-1.0 M. According to its optimum salt concentration and $\mathrm{pH}$ for growth, this isolate was a moderately halophilic, alkaliphilic bacterium. The 165 RNA gene sequence ( $303 \mathrm{nt}$ ) was identical for all three isolates and most closely resembled those of the moderately halophilic eubacteria of the family Halomonadaceae (91\% identity). Biochemical and genetic examination revealed strain I-18 utilizes the same 2,4-D degradation pathway as most of the 2,4-D-degrading bacteria from nonextreme environments. Hybridization data and comparison of the partial sequences of the tfdA gene from the Alkali Lake isolates with those of bacteria from non-extreme environments suggested a common genetic origin of the 2,4-D degradation pathway in the two groups of micro-organisms.

Keywords: Halomonadaceae, 2,4-dichlorophenoxyacetic acid, degradation of chloroaromatic compounds, halophilic bacteria, alkaliphilic bacteria

\section{INTRODUCTION}

The critical role of micro-organisms in the degradation of organic pollutants is well known. Although the microorganisms capable of degradation of organic pollutants and their catabolic pathways have been investigated intensively, information on the microbial degradation of xenobiotics in environments of high salinity and alkalinity is still very limited (Oren et al., 1992). Comparison of analogous catabolic enzymes and pathways of phylogenetically diverse bacteria isolated from extreme and moderate

\footnotetext{
†Present address: Division of Physical Sciences Scarborough Campus, University of Toronto, 1265 Military Trail, Scarborough, Ontario M1C 1A4, Canada.

Abbreviation: 2,4-D, 2,4-dichlorophenoxyacetic acid.

The GenBank accession numbers for the partial nucleotide sequences of the tfdA gene and 165 ribosomal RNA from the Alkali Lake isolates reported in this paper are U22499 and U22836, respectively. (The two sequences were identical in the three isolates studied.)
}

environments should provide information regarding their metabolic diversity. The study of xenobiotic-degrading extremophiles may also help in evaluating their use in bioremediation of contaminated saline and/or alkaline environments.

The 2,4-dichlorophenoxyacetic acid (2,4-D) degradation pathway is one of the best understood, and provides a good model for such investigations. This herbicide has been released into the environment for more than 40 years, and is degraded in soils fairly rapidly. Many bacteria of different genera are able to completely degrade 2,4-D (Don \& Pemberton, 1981; Chaudhry \& Chapalamadugu 1991; Häggblom, 1992). Degradation of 2,4-D via oxidative cleavage of the ether bond with subsequent chlorophenol hydroxylation followed by the modified ortho-cleavage pathway of chlorocatechols has been demonstrated for most of these isolates. This pathway has been most extensively studied using Alcaligenes eutrophus strain JMP134(pJP4) (Don \& Pemberton, 1981, 1985). The enzymes participating in the 2,4-D degradation pathway 


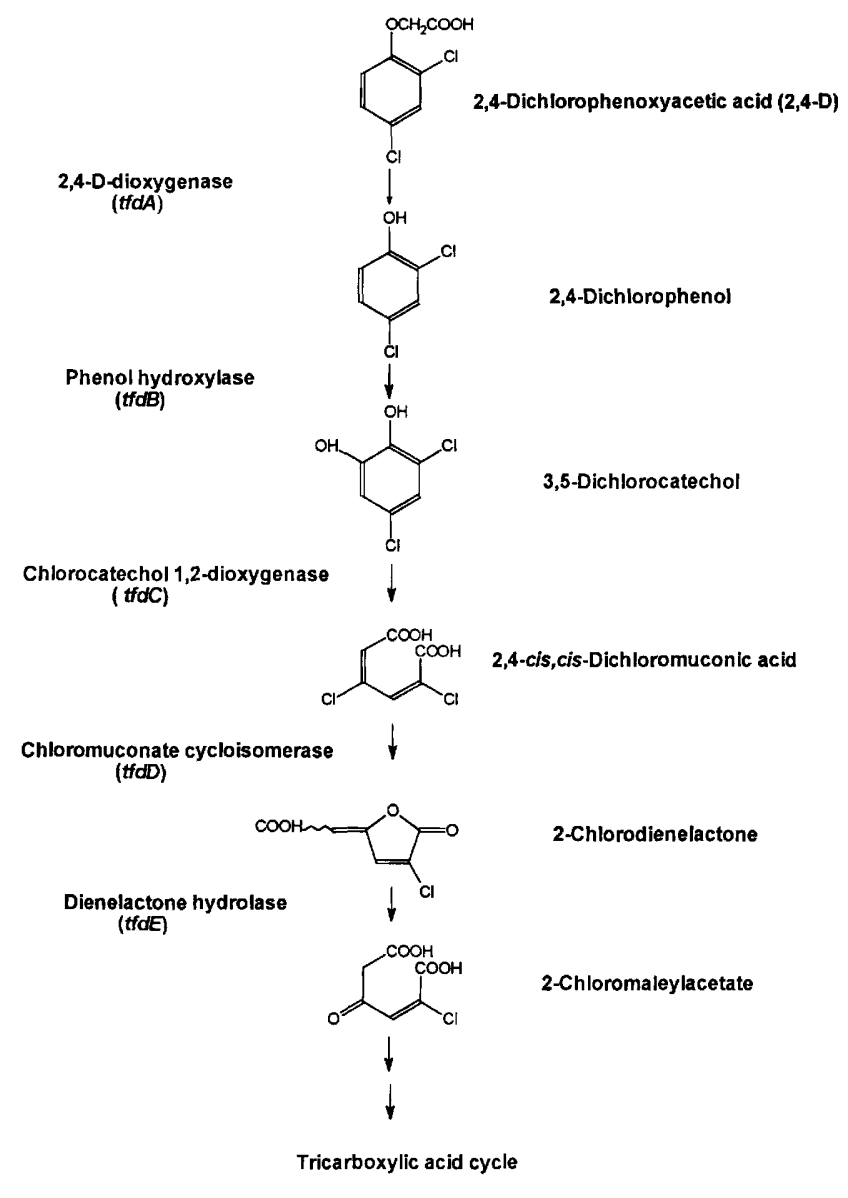

Fig. 1. Pathway for the degradation of 2,4-D in A. eutrophus strain JMP134.

have been purified and characterized, and genes that code for these enzymes ( $t f d A, t f d B, t f d C D E F$ ) have been sequenced (Ghosal \& You, 1988, 1989; Perkins et al., 1990; Kuhm et al., 1990; Schlömann et al., 1990; Häggblom, 1992; Fukumori \& Hausinger, 1993; Seibert et al., 1993). The pathway is summarized in Fig. 1.

We now report on the isolation and characterization of 2,4-D-degrading bacteria of the family Halomonadaceae as a first example of moderately halophilic bacteria capable of complete mineralization of chloroaromatic compounds.

\section{METHODS}

Site description and sample collection. Alkali Lake and West Alkali Lake are hypersaline alkaline lakes in the high desert of southwestern Oregon. The groundwater in the vicinity of the lakes has a salinity near $10 \%$ due to sodium chloride and sodium carbonate, and a $\mathrm{pH}$ of 9.5-10 (Pankow et al., 1984). Between 1969 and 1971 the area separating Alkali Lake and West Alkali Lake was used as a waste storage area. In 1976 approximately 6000 tonnes 2,4-D herbicide production waste were released into the site by the crushing of waste drums in shallow covered trenches. The groundwater in this site is within about $1 \mathrm{~m}$ of the surface and is now contaminated with high levels of monochloro-, dichloro- and trichlorophenols, and also with 2,4D, 4-methyl-2-chlorophenoxyacetic acid and related haloaromatic compounds (Pankow et al., 1984; Johnson et al., 1985). Samples used in this study were taken from soil just above groundwater level across the contaminant plume gradient in April 1993 in cooperation with the State of Oregon Department of Environmental Quality.

Medium. The alkaline mineral medium 1 (AMM1), pH 9·5, was prepared by mixing sterile component $\mathrm{A}\left(20 \mathrm{~g} \mathrm{Na}_{2} \mathrm{CO}_{3}\right.$ and $20 \mathrm{~g}$ $\mathrm{NaHCO}_{3}$ in $300 \mathrm{ml} \mathrm{H} \mathrm{H}_{2} \mathrm{O}$ ), component $\mathrm{B}[40 \mathrm{~g} \mathrm{NaCl}, 3 \mathrm{~g} \mathrm{KCl}$, $0.5 \mathrm{~g} \mathrm{NH}_{4} \mathrm{NO}_{3}, 0.3 \mathrm{~g}\left(\mathrm{NH}_{4}\right)_{2} \mathrm{SO}_{4}, 0.4 \mathrm{~g} \mathrm{MgSO}_{4}, 0.3 \mathrm{~g} \mathrm{NaH}_{2} \mathrm{PO}_{4}$ and trace elements (Imhoff \& Trüper, 1977) in $700 \mathrm{ml} \mathrm{H}_{2} \mathrm{O}$ ] and vitamins (Wolin et al., 1963). $\mathrm{MgSO}_{4}, \mathrm{NaH}_{2} \mathrm{PO}_{4}$ and vitamins were made as $1000 \times$ stock solutions and sterilized separately. Alkaline mineral medium 2, $\mathrm{pH} 9 \cdot 4$, with decreased carbonate concentration (AMM2) was used in some experiments. It contained $5 \mathrm{~g} \mathrm{Na}_{2} \mathrm{CO}_{3}$ and $5 \mathrm{~g} \mathrm{NaHCO}_{3}$ in component $\mathrm{A}$. AMM agar was prepared by adding $20 \mathrm{~g}$ agar to component $\mathrm{B}$ before sterilization. Prior to mixing, all solutions were cooled to room temperature or, in the case of AMM agar media, at least to about $45^{\circ} \mathrm{C}$. The carbon sources and their concentrations were 2,4-D (50-3000 $\left.\mathrm{mg} \mathrm{l}^{-1}\right)$ and yeast extract $\left(50-500 \mathrm{mg} \mathrm{l}^{-1}\right)$.

Enrichment. Soil samples collected at six points across the contaminant plume gradient were combined. Subsamples $(5 \mathrm{~g})$ of the mixture was added to $200 \mathrm{ml}$ AMM1 in Erlenmeyer flasks and incubated aerobically at 30 or $37^{\circ} \mathrm{C}$. Cultures were grown statically or on a rotary shaker at 200 r.p.m. 2,4-D $\left(50 \mathrm{mg} \mathrm{l}^{-1}\right)$ was used as the only carbon source. In the case of complete disappearance of 2,4-D from entichment cultures, repeated additions (from two to five) were used to supply microorganisms with growth substrate. The ability to degrade 2,4-D was evaluated by HPLC and by measurement of the ${ }^{14} \mathrm{CO}_{2}$ evolution from ${ }^{14} \mathrm{C}$-labelled 2,4-D (see below). Enrichments demonstrating 2,4-D degradation $(5 \mathrm{ml})$ were transferred to fresh AMM1 (50 ml) containing $50 \mathrm{mg}$ yeast extract $\mathrm{l}^{-1}$ and $200 \mathrm{mg} \mathrm{2,4-D} \mathrm{^{-1 }}$. These enriched samples were plated onto

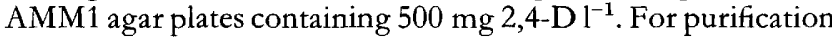
of isolates, single colonies were selected and transferred onto AMM1 plates containing $500 \mathrm{mg} 2,4-\mathrm{D} \mathrm{l}^{-1}$. Confirmation of 2,4$\mathrm{D}$ degradation was carried out by inoculating each isolate into liquid AMM1 containing $50 \mathrm{mg}$ yeast extract $\mathrm{l}^{-1}$ and $200 \mathrm{mg}$ 2,4-D ${ }^{-1}$ and determination of both increase of $\mathrm{OD}_{550}$ and disappearance of herbicide. Liquid AMM1 with the same concentrations of yeast extract and 2,4-D, but without microbial cultures, was used as a control.

Catabolism of ${ }^{14} \mathrm{C}$-labelled 2,4-D. For isotopic experiments, the reaction mixture contained in a $1.5 \mathrm{ml}$ microcentrifuge tube $0.25 \mathrm{ml} \mathrm{AMM1}, 0.25 \mathrm{ml}$ enrichment cultures and $50 \mathrm{mg} \mathrm{l}^{-1}$ ringlabelled 2,4-D [Sigma, specific activity $20 \cdot 2 \mathrm{mCi}^{\mathrm{mmol}}{ }^{-1}$ $\left(747 \mathrm{MBq} \mathrm{mmol}^{-1}\right.$ ), $0.05 \mu \mathrm{Ci}$ per sample]. A control tube contained only labelled 2,4-D and AMM1 without enrichment cultures. The tubes were inserted into scintillation vials containing on the bottom $1 \mathrm{ml}$ phenethylamine as a trapping agent. Vials were closed with caps and incubated on a rotary shaker at 150 r.p.m. for $3 \mathrm{~d}$. At the end of the incubation period the microcentrifuge tubes were removed from the scintillation vials and $10 \mathrm{ml}$ of the Bio-Safe II scintillation cocktail was added to the trapping agent. Radioactivity was measured using an LKB 1211 Rackbeta liquid scintillation counter with appropriate correction for quenching.

High performance liquid chromatography (HPLC). This was performed with a Hewlett-Packard series 1050 chromatograph equipped with a multiple wavelength detector set at $230 \mathrm{~nm}$. Separation was achieved on a reversed-phase Lichrosorb RP-18 column (Merck) of internal diameter $4 \mathrm{~mm}$ and length $250 \mathrm{~mm}$. 
The flow rate was $1.5 \mathrm{ml} \mathrm{min}^{-1}$. Compounds were detected at $230 \mathrm{~nm}$. The mobile phase was an aqueous solution of $40 \%$ $(\mathrm{v} / \mathrm{v})$ methanol and $0 \cdot 1 \%(\mathrm{w} / \mathrm{v}) \mathrm{H}_{3} \mathrm{PO}_{4}$.

Utilization of other aromatic compounds as sources of carbon and energy. Growth on aromatic compounds was measured in AMM with benzoic, 3-hydroxy- and 4-hydroxybenzoic acids supplied at $300 \mathrm{mg} \mathrm{l}^{-1} ; 2$-chloro-, 3-chloro- and 4-chlorobenzoic acids, and 2-methyl-4-chlorophenoxyacetic acid supplied at $150 \mathrm{mg} \mathrm{I}^{-1}$; and monochlorophenols, 2,4-dichloro-, 2,6dichloro- and 2,4,6-trichlorophenol, and 2,4,5trichlorophenoxyacetic acid supplied at $30 \mathrm{mg} \mathrm{l}^{-1}$. Cultures were analysed for increase in OD and removal of the aromatic compound from the medium.

Determination of optimal growth conditions. The specific growth rates under various conditions were analysed during exponential growth by linear regression of the logarithm of $\mathrm{OD}_{550}$ with time. Salt dependency of growth was determined in AMM1 and AMM2 containing various concentrations of $\mathrm{NaCl}$ $(0-1.8 \mathrm{M})$ in component $\mathrm{B}$. To determine the $\mathrm{pH}$ optima for growth, media $\mathrm{pH}$ was varied by mixing component $\mathrm{B}$ of $\mathrm{AMM}$ with various buffer systems: $40 \mathrm{mM}$ HEPES, $\mathrm{pH} \mathrm{6.8-7.5}$; $40 \mathrm{mM}$ Tris, $\mathrm{pH} 7 \cdot 1-8.9$; and $200 \mathrm{mM} \mathrm{Na} \mathrm{CO}_{3} / \mathrm{NaHCO}_{3}$ buffer, $\mathrm{pH} 8 \cdot 6-10 \cdot 6$. The $\mathrm{pH}$ values reported here are the initial ones, but they varied less then $0 \cdot 2$ units during growth of the culture. All media were supplemented with $\mathrm{NaCl}$ to keep the sodium ion concentration near $0.8 \mathrm{M}$.

Fatty acid analysis. The fatty acid methyl ester analysis of lipids was performed by MIDI Laboratories (Newark, DE). Isolate I18 was precultured on AMM1 agar supplemented with 2 g 2,4$\mathrm{D}^{-1}$ and streaked onto plates of tryptic soy agar (TSA) containing $10 \%(\mathrm{w} / \mathrm{v}) \mathrm{NaCl}$. Plates were incubated for $4 \mathrm{~d}$. Saponification, methylation and extraction were performed as described by Sasser \& Wichman (1991)

Preparation of cell-free extracts and enzyme assay. Strain I-

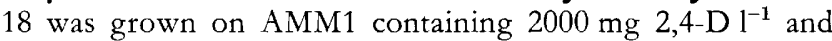
$50 \mathrm{mg}$ yeast extract $\mathrm{l}^{-1}$ for $36 \mathrm{~h}$, then harvested by centrifugation and washed twice with $50 \mathrm{mM}$ Tris $/ \mathrm{HCl}$ buffer, $\mathrm{pH} 8.0$ containing $0.1 \mathrm{mM}$ dithiothreitol and $2 \mathrm{mM} \mathrm{MnSO}_{4}$. After disruption of the cells by sonication for $2 \mathrm{~min}$ at $0^{\circ} \mathrm{C}$, cell-free extracts were separated from whole cells and cell debris by centrifugation at $25000 \mathrm{~g}$ for $40 \mathrm{~min}$ at $5^{\circ} \mathrm{C}$.

Activities of the modified ortho-cleavage pathway enzymes were measured spectrophotometrically using a Perkin-Elmer Coleman 124 instrument (USA). One unit of enzyme activity was defined as the amount of enzyme that catalysed the formation of $1 \mu \mathrm{mol}$ product $\mathrm{min}^{-1}$ at room temperature. Activities of chlorocatechol 1,2-dioxygenase (EC 1.13.11.1), chloromuconate cycloisometase (EC 5.5.1.7) and dienelactone hydrolase (EC 3.1.1.45) were determined as described previously (Dorn \& Knackmuss, 1978; Maltseva et al., 1994).

Protein concentrations were determined using a Bio-Rad Protein Assay Kit with bovine serum albumin as a standard.

DNA extraction and Southern hybridization. Strain I-18 was cultured with 2,4-D as growth substrate as described above. Strains P-3 and I-17 were grown on AMM1 containing $1 \mathrm{~g}$ sodium pyruvate $\mathrm{l}^{-1}$ and $200 \mathrm{mg} 2,4-\mathrm{Dl}^{-1}$. The miniprep method of Ausubel et al. (1987) was used to extract total genomic DNA. EcoRI-digested DNA was separated by gel electrophoresis on an $0.8 \%(\mathrm{w} / \mathrm{v})$ agarose gel and blotted onto Hybond-N nylon membranes (Amersham). The probes were internal segments of the $t f d A, t f d B, t f d C$ and $t f d D$ genes of $A$. eutropbus JMP134(pJP4) (Holben et al., 1992). All probes were labelled with digoxigenin dUTP using a DNA labelling kit (BoehringerMannheim) according to the manufacturer's instructions. Hybridizations were performed at three different stringencies as described by Fulthorpe et al. (1995).

PCR amplification and sequencing of PCR products. The $16 \mathrm{~S}$ ribosomal RNA genes were amplified using $\mathrm{rD} 1$ and $\mathrm{fD} 1$ primers (Weisburg et al., 1991). The $t f d A$ genes were amplified using primers TV1 and TV2 designed by Tatiana Vallaeys and Alice Wright and synthesized at the Macromolecular Facility, Michigan State University (Vallaeys et al., 1996). The PCR reaction mixtures were prepared according to the manufacturer's protocol (Perkin Elmer Cetus). Thermal cycling was done in a Perkin Elmer 9700 Thermal Cycler using the following conditions: melting at $92{ }^{\circ} \mathrm{C}$ for 1 min; cycling 35 times at $92^{\circ} \mathrm{C}$ for $1 \mathrm{~min} 10 \mathrm{~s}, 55^{\circ} \mathrm{C}$ for $30 \mathrm{~s}$ and $72^{\circ} \mathrm{C}$ for $2 \mathrm{~min} 10 \mathrm{~s}$; followed by a final extension at $72{ }^{\circ} \mathrm{C}$ for $6 \mathrm{~min} 10 \mathrm{~s}$. Amplified products were purified using a Gene Clean kit (BIO 101). Sequencing was carried out at Michigan State University Sequencing Facility using the Applied Biosystems Model 373A automatic sequencer (Perkin Elmer Cetus) and fluorescently labelled dye termination. The sequencing primer used for $16 \mathrm{~S}$ was $519 \mathrm{R}$ (5'-GTA TTA CCG CGG CTG CTG G-3') (Lane et al., 1985). Partial sequences were compared to data in GenBank using the Basic Local Alignment Search Tool (BLAST) from the National Center for Biotechnology Information (Altschul et al., 1990) and also the database of the Ribosomal Database Project (Larsen et al., 1993).

Chemicals. Catechol was purchased from Sigma and 4chlorocatechol from Helix Biotech Corporation. 3Chlorocatechol and 3,5-dichlorocatechol, and cis-dienelactone were kind gifts from M. Schlömann, Universität Stuttgart, and $W$. Reineke, Bergische Universität-Gesamthochschule Wuppertal, respectively. Chloromuconic acids were prepared as described by Kuhm et al. (1990) using partially purified chlorocatechol dioxygenase kindly supplied by M. Schlömann and M. Vollmer, Universität Stuttgart.

\section{RESULTS}

\section{Characterization of isolates}

Three strains able to degrade 2,4-D were isolated from the enrichments and designated P-3, I-17 and I-18. On AMM1 agar supplemented with $1 \mathrm{~g}$ yeast extract $1^{-1}$ and $1 \mathrm{~g}$ Casamino acids $\mathrm{l}^{-1}$ these bacteria initially produced small transparent colonies, progressing into yellow colonies with tan pigmentation in the centre and a lobate edge. The isolates grew well at $30^{\circ} \mathrm{C}$, but no growth was observed at $37^{\circ} \mathrm{C}$. All strains were Gram-negative, motile rods. Electron microscopy revealed cells of isolate I-18 to be about $1.7-1.9 \mu \mathrm{m}$ in length and about $0.6-0.7 \mu \mathrm{m}$ in diameter (data not shown).

The sequences of approximately 303 nucleotides, corresponding to the $E$. coli $16 \mathrm{~S} \mathrm{RNA}$ gene sequence from $\mathrm{nt}$ 211 to 513 , were identical for all three isolates and showed strong similarity to $16 \mathrm{~S}$ RNA sequences of the moderately halophilic eubacteria. The highest identity was found with Halomonas elongata A TCC 33173 (91.4\%), Halovibrio variabilis DSM 3051 (91.1\%), Deleya balophila DSM 4770 $(89 \cdot 8 \%)$, Halomonas meridiana DSM $5425(89 \cdot 8 \%)$ and Deleya marina ATCC 25374 (89.8\%).

The major fatty acids of isolate I-18 and their concentration ranges were 10:0 (3.56-4.52\%), 12:0 3-OH $(2 \cdot 81-3.58 \%), 14: 0(1.94-2 \cdot 40 \%), 16: 0(8 \cdot 46-9.06 \%)$, $16: 1$ cis $9(12 \cdot 24-15 \cdot 48 \%), 17: 0$ cyclo $(4 \cdot 90-5 \cdot 90 \%)$ and 


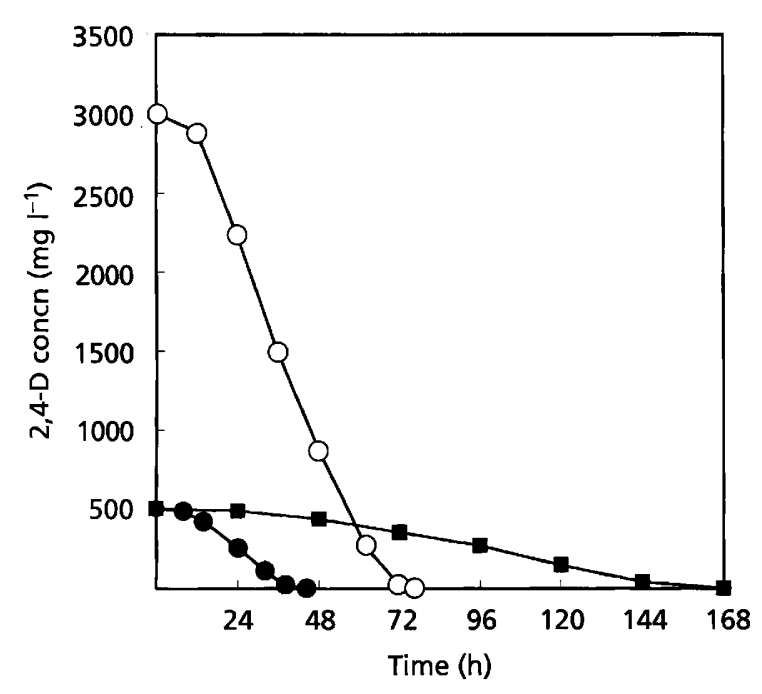

Fig. 2. Influence of yeast extract on 2,4-D degradation by strain 1-18. Cells were grown on AMM1, $\mathrm{pH} 9.5$, containing 2,4-D $\left(500 \mathrm{mg} \mathrm{l}^{-1}\right)(\mathbb{D})$ or $2,4-\mathrm{D}$ (500 or $3000 \mathrm{mg} \mathrm{l}^{-1}$ ) plus yeast extract $\left(50 \mathrm{mg} \mathrm{I}^{-1}\right)(0,0)$.

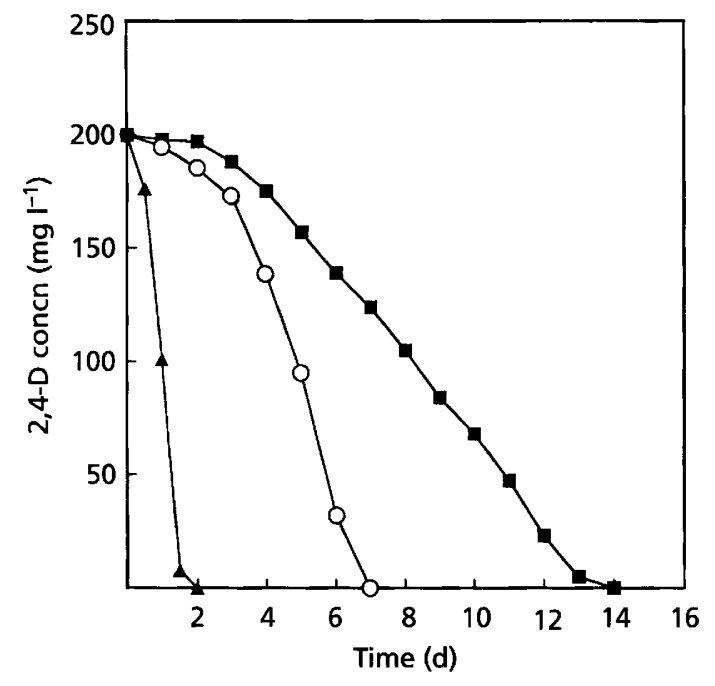

Fig. 3. Degradation of 2,4-D by Alkali Lake isolates I-18 (A), P-3 (O) and I-17 ( $($ ) in AMM1, pH 9.5, supplemented with $50 \mathrm{mg}$ yeast extract $\mathrm{I}^{-1}$

an unresolved mixture of $18: 1(54 \cdot 54-56 \cdot 57 \%)$ and $19: 0$ cyclo $11-12(4 \cdot 41-6 \cdot 38 \%)$.

\section{Dynamics of 2,4-D degradation}

Although the Alkali Lake isolates were able to grow on minimal alkaline medium with 2,4-D as single carbon and energy source, addition of a trace of yeast extract greatly increased the rate of 2,4-D degradation (Fig. 2; data for isolates I-17 and P-3 not shown). While similar in appearance and colony morphology, the three isolates demonstrated significant differences in ability to metabolize 2,4-D (Fig. 3). The growth range and degradation ability of the most active isolate I-18 were examined in more detail. When supplemented with $50 \mathrm{mg}$ yeast extract $\mathrm{I}^{-1}$, strain I-18 demonstrated an ability to degrade $3000 \mathrm{mg}$ $2,4-\mathrm{D}^{-1}$ over a $3 \mathrm{~d}$ period. This strain was able to utilize other aromatic compounds including benzoic acid, $m$ hydroxy- and p-hydroxybenzoic acid, 3-chlorobenzoic acid and, less efficiently, 4-chlorophenol and 2,4dichlorophenol (data not shown). Growth was not observed with 2-chloro- or 4-chlorobenzoic acid, 2chloro- or 3-chlorophenol or 2,4,5-trichlorophenoxyacetic acid.

\section{Salt effects on the growth of strain I-18}

Different $\mathrm{NaCl}$ optima were observed during growth of isolate I-18 in AMM1 and AMM2 containing different amounts of sodium carbonates (Fig. 4a). When specific growth rates were plotted against total sodium ion concentration, however, almost coincident curves were obtained, indicating the strong growth response to sodium ions and lesser dependence of growth on carbonate or chloride concentration (Fig. 4b). This organism was able to grow over a wide range of salt concentrations on both yeast extract and 2,4-D. However, the use of complex media supported growth over a wider range of $\mathrm{NaCl}$ concentrations than did defined media. The optimal sodium ion concentration for growth was the same on both defined and complex media $(0 \cdot 6-1 \cdot 0 \mathrm{M})$, and no growth was observed below $0 \cdot 1 \mathrm{M}$.

\section{pH effects on the growth of strain 1-18}

This was studied in media of different $\mathrm{pH}$ and a sodium ion concentration of approximately $0.8 \mathrm{M}$. The bacterium was able to grow on yeast extract over a wide $\mathrm{pH}$ range $(6 \cdot 5-10 \cdot 5)$ and had a broad pH optimum (8.2-9.6) (Fig. 5). When grown on defined medium with $2,4-\mathrm{D}$, a more narrow $\mathrm{pH}$ range of the growth was found $(7 \cdot 4-9 \cdot 8)$ with the optimum between $8 \cdot 4$ and $9 \cdot 4$.

\section{Degradation pathway of isolate I-18}

High activities of catechol 1,2-dioxygenase, muconate cycloisomerase and dienelactone hydrolase were detected in cell-free extracts of isolate I-18 grown on 2,4-D (Table 1). Activities of catechol 1,2-dioxygenase and muconate cycloisomerase were higher with chlorinated than with unsubstituted substrates. The data suggest that haloalkaliphilic strain I-18, like the well-studied strain $A$. eutrophus JMP134(pJP4), uses the modified ortho-cleavage pathway for 2,4-D degradation.

\section{Genetic comparison of the 2,4-D degradation pathway in bacteria from extreme and non-extreme environments}

No hybridization of the DNA from the Oregon isolate I18 with the $\mathrm{pJP} 4$ genes $t f d A, t f d B, t f d C$ and $t f d D$ encoding the first four steps of the 2,4-D degradation pathway in $A$. eutrophus JMP134 was found at high stringency, but positive signals were observed with $t f d A, t f d B$ and $t f d D$ probes at medium stringency and very weak hybridization 

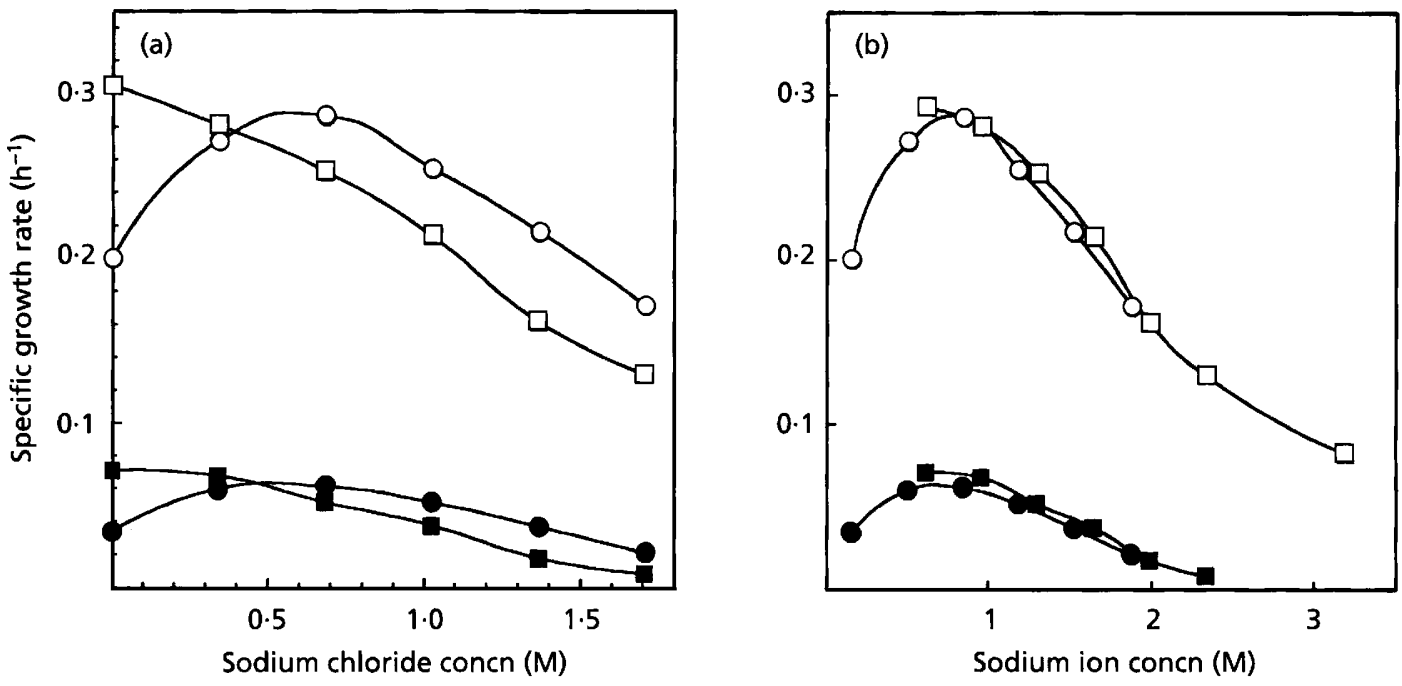

Fig. 4. Influence of sodium chloride (a) and sodium ion concentration (b) on growth of isolate I-18 on yeast extract $\left(500 \mathrm{mg} \mathrm{l}^{-1}\right.$; open symbols) and on 2,4-D $\left(500 \mathrm{mg} \mathrm{l}^{-1}\right)$ plus yeast extract (50 $\left.\mathrm{mg} \mathrm{l}^{-1}\right)$ (filled symbols). Cells were grown in AMM1, pH 9.5, containing $20 \mathrm{~g} \mathrm{Na}_{2} \mathrm{CO}_{3} \mathrm{l}^{-1}$ and $20 \mathrm{~g} \mathrm{NaHCO}_{3} \mathrm{I}^{-1}(\square, \square)$ or in AMM2, pH 9.4, containing $5 \mathrm{~g} \mathrm{Na}_{2} \mathrm{CO}_{3} \mathrm{I}^{-1}$ and $5 \mathrm{~g} \mathrm{NaHCO}_{3} \mathrm{I}^{-1}(\mathrm{O}, 0)$. Both media were supplemented with different concentations of sodium chloride.

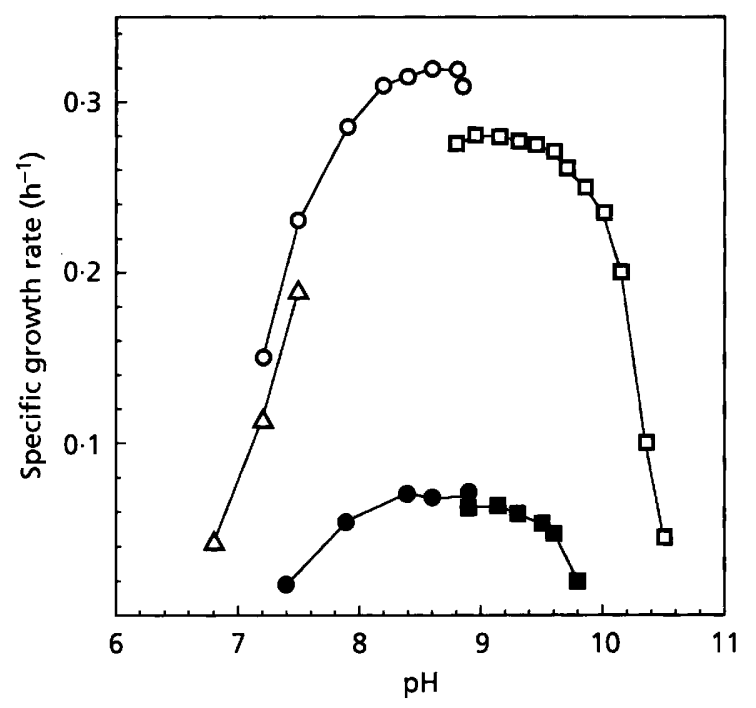

Fig. 5. Influence of $\mathrm{pH}$ on growth of isolate $\mathrm{I}-18$ on yeast extract ( $500 \mathrm{mg} \mathrm{I}^{-1}$; open symbols) or on 2,4-D $\left(500 \mathrm{mg} \mathrm{l}^{-1}\right)$ plus yeast extract $\left(50 \mathrm{mg}^{-1}\right)$ (filled symbols). The $\mathrm{pH}$ values of the media were adjusted with the following buffer systems: $40 \mathrm{mM}$ HEPES/NaOH $(\mathrm{pH} \mathrm{6.8-7.5)} \mathrm{( \triangle ),} 40 \mathrm{mM}$ Tris/HCl $(\mathrm{pH} 7 \cdot 1-8.9)(\mathrm{O}$, ๑), and $200 \mathrm{mM} \mathrm{Na} \mathrm{CO}_{3} / \mathrm{NaHCO}_{3}$ (pH 8.6-10.6) ( $\square$, $\square$ ). All media were supplemented with $\mathrm{NaCl}$ to keep the sodium ion concentration near $0.8 \mathrm{M}$.

with $t f d C$ was found at low stringency (Fig. 6). Hybridization patterns for all three Alkali Lake isolates were identical (data for isolates I-17 and P-3 not shown). The sizes of all DNA restriction fragments of these isolates hybridizing with $t f d A-D$ differed from those of $\mathrm{pJP} 4$.

The $t f d A$ genes from the Alkali Lake isolates were PCRamplified and the products sequenced. The sequences of
Table 1. Enzyme activities in cell extracts of 2,4-D-grown cells of isolate $\mathrm{I}-18$

\begin{tabular}{|c|c|c|c|}
\hline Enzyme & Substrate & $\begin{array}{c}\text { Specific } \\
\text { activity } \\
{[\mathrm{mU}(\mathrm{mg}} \\
\left.\text { protein })^{-1}\right]\end{array}$ & $\begin{array}{c}\text { Relative } \\
\text { activity } \\
(\%)^{*}\end{array}$ \\
\hline \multirow{4}{*}{$\begin{array}{l}\text { Catechol 1,2- } \\
\text { dioxygenase }\end{array}$} & Catechol & 110 & 100 \\
\hline & 3-Chlorocatechol & 61 & 55 \\
\hline & 4-Chlorocatechol & 81 & 74 \\
\hline & 3,5-Dichlorocatechol & 188 & 171 \\
\hline \multirow{4}{*}{$\begin{array}{l}\text { Muconate } \\
\text { cycloisomerase }\end{array}$} & cis, cis-Muconate & 17 & 100 \\
\hline & $\begin{array}{l}\text { 2-Chloro-cis, cis- } \\
\text { muconate }\end{array}$ & 43 & 252 \\
\hline & $\begin{array}{l}\text { 3-Chloro-cis, cis- } \\
\text { muconate }\end{array}$ & 56 & 329 \\
\hline & $\begin{array}{l}\text { 2,4-Dichloro-cis, cis- } \\
\text { muconate }\end{array}$ & 33 & 194 \\
\hline $\begin{array}{l}\text { Dienelactone } \\
\text { hydrolase }\end{array}$ & cis-Dienelactone & 65 & \\
\hline
\end{tabular}

* Relative activities of catechol 1,2-dioxygenase and muconate cycloisomerase are expressed as a percentage of the value with catechol and muconate, respectively.

approximately 317 nucleotides, corresponding to the $A$. eutrophus JMP134tfd $A$ gene sequence from nt 449-765, were identical for all three isolates. The partial sequences of these isolates showed strong similarity to $\operatorname{tfd} A$ sequences of Burkbolderia sp. strain RASC (formerly Pseudomonas sp. TFD3) and A. eutrophus JMP134 (94\% and $77 \%$ identity, respectively) (Perkins et al., 1990; Suwa 


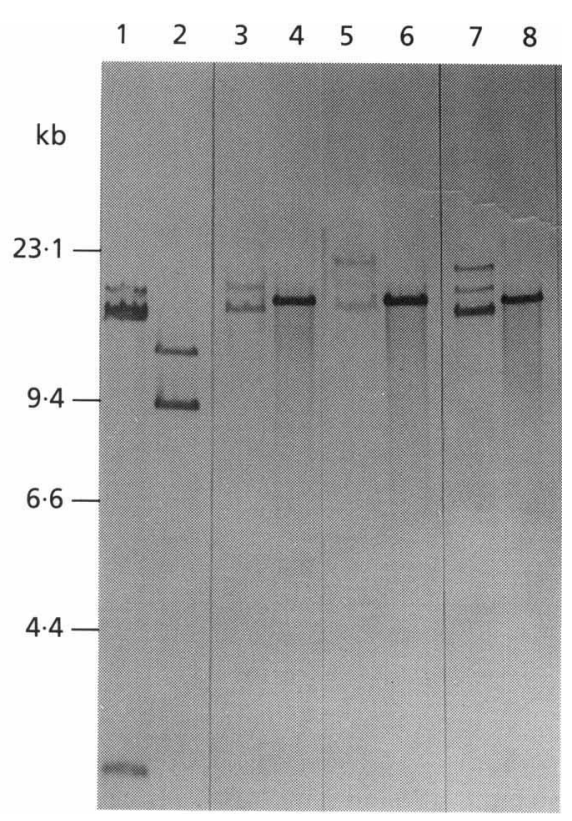

Fig. 6. Low stringency hybridization of pJP4-derived probes $t f d A$ (lanes 1 and 2), $t f d B$ (lanes 3 and 4), tfdC (lanes 5 and 6) and $\operatorname{tfd} D$ (lanes 7 and 8 ) with DNA from Alkali Lake isolate I-18 (lanes 1, 3, 5 and 7) and A. eutrophus JMP134(pJP4) (lanes 2, 4, 6 and 8) digested with EcoRI.

et al., 1994) and were identical to that of strains B6-9 and TFD31 (nucleotide accession number U43196) which were tentatively identified as Rbodoferax fermentans (Fulthorpe et al., 1995).

\section{DISCUSSION}

Three bacterial isolates capable of complete mineralization of 2,4-D were obtained from the highly saline and alkaline Alkali Lake site. The most active strain, I-18, was welladapted to the extreme environment from which it was isolated, growing optimally at a sodium ion concentration near $0 \cdot 6-1 \cdot 0 \mathrm{M}$ and at $\mathrm{pH} 8 \cdot 4-9 \cdot 4$. According to the classification of Kushner \& Kamekura (1988), this isolate is a moderately halophilic bacterium. Since microorganisms with $\mathrm{pH}$ optima for growth in excess of $\mathrm{pH} 8$ are defined as alkaliphiles (Grant \& Tindall, 1986), strain I-18 should be regarded as a moderately halophilic, alkaliphilic bacterium.

The partial 16S RNA sequences of the three 2,4-D degrading isolates from the Alkali Lake site indicate that they are members of the gamma subdivision of the Proteobacteria and belong to the family Halomonadaceae, which unifies moderately halophilic eubacteria (Dobson $e t$ al., 1993; Franzmann \& Tindall, 1990; Franzmann et al., 1988). The 16S RNA sequences obtained for the Alkali Lake isolates had cytosine at position 486 (Escherichia coli numbering), as have all the other members of this family examined so far, which is an extremely rare attribute among the prokaryotes (Dobson et al., 1993). It has been shown recently that the three genera of the family
Halomonadaceae (Halomonas, Deleya and Halovibrio) cannot be resolved on the basis of phylogenetic, chemotaxonomic or phenotypic data and unification of these genera in a single genus has been proposed (Dobson et al., 1993). Until the taxonomy of this group is clarified it is not feasible to assign these bacteria to a species or genus. The close taxonomic relationship of the Alkali Lake isolates and the Halomonadaceae indicated by the 16S RNA sequencing data is consistent with the finding that isolate I-18 is a moderately halophilic bacterium. In addition the major fatty acids of isolate I- $18(16: 0,16: 1,17: 0 \mathrm{cyc}, 18: 1$ and $19: 0 \mathrm{cyc}$ ), representing $90 \%$ of the total fatty acids, are the same as for other members of the Halomonadaceae (Franzmann \& Tindall, 1990).

The alkaliphilicity of Halomonadaceae strain I-18 is not surprising as it is known that some bacteria of this family are capable of growth at $\mathrm{pH} 9$ and even $\mathrm{pH} 10$ (Del Moral et al., 1988; V reeland et al., 1980). Recently, it was shown that two groups of alkaliphilic isolates from Kenyan Soda Lakes also belong to the Halomonadaceae (Jones et al., 1994).

The Alkali Lake isolates are the first known aerobic, halophilic bacteria able to use chloroaromatic compounds as sources of carbon and energy. Enzyme activities of strain I-18 suggest that it utilizes the same pathway of 2,4$\mathrm{D}$ degradation as the majority of 2,4-D-degrading bacteria from non-extreme environments (Häggblom, 1992). Since the contamination of the Alkali Lake site with chloroaromatic compounds is recent, the origin of the 2,4-D degradation pathway in the haloalkaliphilic bacteria is of interest. The DNA from all three Alkali Lake isolates hybridized to $\mathrm{pJP} 4$ genes $t f d A, t f d B, t f d C$ and $t f d D$, responsible for 2,4-D degradation in the well-known 2,4D-degrading bacterium $A$. eutrophus JMP134. Moreover, the partial sequences of the $t f d A$ genes from the Alkali Lake isolates were only slightly different from the sequence of the $t f d A$ gene of $A$. eutrophus JMP134 and identical to that of the 2,4-D-degrading strains $R$. fermentans B6-9 and TFD31 isolated from non-extreme environments in Ontario and Southern Saskatchewan, respectively (Fulthorpe, 1991; Tonso et al., 1995). These data suggest a common origin of the genes encoding 2,4$\mathrm{D}$ degradation in the haloalkaliphilic bacteria and bacteria from non-extreme environments.

An interesting characteristic of moderately halophilic eubacteria is their mode of osmoadaptation. In contrast to the extremely halophilic Archaea that have high intracellular potassium and sodium ion concentrations and enzymes adapted to this environment (Hochstein, 1988), moderately halophilic bacteria can extensively accumulate organic osmolytes called 'compatible solutes' which do not interfere with cell metabolism and may even contribute to enzyme stability (Galinski, 1993). It is not clear whether the enzymes of moderately halophilic eubacteria have special adaptive changes to function optimally in an environment of high osmolarity (Kushner \& Kamekura, 1988). The data obtained in this investigation indicate that very similar TfdA enzymes can function efficiently in both halophilic and non-halophilic eubacteria. Complete 
sequencing of the genes encoding 2,4-D degradation in strain I-18, and study of catabolic gene transfer between halophilic and non-halophilic eubacteria should more firmly establish the compatibility of the enzymes from both groups of micro-organisms and the requirements for engineering xenobiotic-degrading halophilic eubacteria.

\section{ACKNOWLEDGEMENTS}

This work was supported by National Science Foundation Science and Technology Center Grant No. BIR 9120006.

We wish to thank Brian McClure of the Oregon Department of Environmental Quality for assistance in sample collection. We are grateful to Helen Gorlew for performing the FAME analysis and to Jacqueline Wood of the MSU Center for Electron Optics for the scanning electron microscopy. We thank Tatiana Vallaeys and Alice Wright for designing the primers used to amplify DNA from $t f d A$ genes. We are grateful to $\mathrm{M}$. Schlömann and M. Vollmer for supplying 3-chlorocatechol, 3,5-dichlorocatechol and partially purified chlorocatechol 1,2dioxygenase and to $\mathrm{W}$. Reineke for cis-dienelactone. We also thank Eva Top and Cindy Nakatsu for helpful advice.

\section{REFERENCES}

Altschul, S. F., Gish, W., Miller, M., Myers, E. W. \& Lipman, D. J. (1990). Basic local alignment search tool. J Mol Biol 215, 403-410.

Ausubel, F. M., Brent, R., Kingston, R. E., Moore, D. D., Smith, J. A., Seidman, J. G. \& Struhl, K. (1987). Current Protocols in Molecular Biology. New York: John Wiley.

Chaudhry, G. R. \& Chapalamadugu, S. (1991). Biodegradation of halogenated organic compounds. Microbiol Rev 55, 59-79.

Del Moral, A., Prado, B., Quesada, E., García, T., Ferrer, R., \& Ramos-Comenzana, A. (1988). Numerical taxonomy of moderately halophilic Gram-negative rods from an inland saltern. $J$ Gen Microbiol 134, 733-741.

Dobson, S. J., McMeekin, T. A. \& Franzmann, P. D. (1993). Phylogenetic relationships between some members of the genera Deleya, Halomonas, and Halovibrio. Int J Syst Bacteriol 43, 665-673.

Don, R. H. \& Pemberton, J. M. (1981). Properties of six pesticide degradation plasmids isolated from Alcaligenes eutrophus and Alcaligenes paradoxus. J Bacteriol 145, 681-686.

Don, R. H. \& Pemberton, J. M. (1985). Genetic and physical map of the 2,4-dichlorophenoxyacetic acid-degradative plasmid pJP4. $J$ Bacteriol 161, 466-468.

Dorn, E. \& Knackmuss, H.-J. (1978). Chemical structure and biodegradability of halogenated aromatic compounds. Two catechol 1,2-dioxvgenases from a 3-chlorobenzoate grown pseudomonad. Biocbem J 174, 73-84.

Franzmann, P. D. \& Tindall, B. J. (1990). A chemotaxonomic study of the members of the family Halomonadaceae. Syst Appl Microbiol 13, 142-147.

Franzmann, P. D., Wehmeyer, U. \& Stackebrandt, E. (1988). Halomonadaceae fam. nov., a new family of the class Proteobacteria to accommodate the genera Halomonas and Deleya. Syst Appl Microbiol $11,16-19$

Fukumori, F. \& Hausinger, R. P. (1993). Purification and characterization of 2,4-dichlorophenoxyacetate/ $\alpha$-ketoglutarate dioxygenase. J Bial Chem 268, 24311-24317.

Fulthorpe, R. R. (1991). Survival, activity and transfer of a bacterial catabolic transposon in an aquatic ecosystem. $\mathrm{PhD}$ thesis, Carleton University, Ottawa.

Fulthorpe, R. R., McGowan, C., Maltseva, O. V., Holben, W. H., \&
Tiedje, J. M. (1995). 2,4-Dichlorophenoxyacetic acid degrading bacteria are mosaics of catabolic genes. Appl Environ Microbiol 61, 3274-3281.

Galinski, E. A. (1993). Compatible solutes of halophilic eubacteria: molecular principles, water-solute interaction, stress protection. Experientia 49, 487-496.

Ghosal, D. \& You, I.-S. (1988). Nucleotide homology and organization of chlorocatechol oxidation genes of plasmids pJP4 and pAC27. Mol Gen Genet 211, 113-120.

Ghosal, D. \& You, I.-S. (1989). Operon structure and nucleotide homology of the chlorocatechol oxidation genes of plasmids pJP4 and pAC27. Gene 83, 225-232.

Grant, W. D. \& Tindall, B. J. (1986). The alkaline saline environment. In Microbes in Extreme Environments, pp. 25-54. Edited by R. A. Herbert \& G. A. Cood. London: Academic Press.

Häggblom, M. M. (1992). Microbial breakdown of halogenated aromatic pesticides and related compounds. FEMS Microbiol Rev 103, 29-72.

Hochstein, L. I. (1988). The physiology and metabolism of the extremely halophilic bacteria. In Halophilic Bacteria, vol. 2, pp. $67-79$. Iidited by F. Rodriguez-Valera. Boca Raton, FL: CRC Press.

Holben, W. E., Schroeter, B. M., Calabrese, V. G. M., Olsen, R. H., Kukor, J. K., Biederbeck, V. O., Smith, A. E. \& Tiedje, J. M. (1992). Gene probe analysis of soil microbial populations selected by amendment with 2,4-dichlorophenoxyacetic acid. Appl Environ Microbiol 58, 3941-3948.

Imhoff, J. F. \& Trüper, H. G. (1977). Ectotbiorbodospira balocbloris sp. nov. a new extremely halophilic phototrophic bacterium containing bacteriochlorophyll b. Arch Microbiol 114, 115-121.

Johnson, R. L., Brillante, S. M., Isabelle, L. M., Houck, J. E. \& Pankow, J. F. (1985). Migration of chlorophenolic compounds at the chemical waste disposal site at Alkali Lake, Oregon. 2. Contaminant distribution, transport, and retardation. Ground $W$ ater 23, 652-666

Jones, B. E., Grant, W. D., Collins, N. C. \& Mwatha, W. E. (1994). Alkaliphiles: diversity and identification. In Bacterial Diversity and Sytematics, pp. 195-230. Edited by F. G. Priest, A. RamosCormenzana \& B. J. Tindall. New York \& London: Plenum Press.

Kuhm, A. E., Schlömann, M., Knackmuss, H.-J. \& Pieper, D. (1990). Purification and characterization of dichloromuconate cycloisomerase from Alcaligenes eutropbus JMP134. Biochem $J$ 266, 877-883.

Kushner, D. J. \& Kamekura, M. (1988). Physiology of halophilic bacteria. In Halopbilic Bacteria, vol. 1, pp. 109-138. Edited by F. Rodriguez-Valera. Boca Raton, FL: CRC Press.

Lane, D. J., Pace, B., Olsen, G. J., Stahl, D. A., Sogin, M. L. \& Pace, N. R. (1985). Rapid determination of $16 S$ ribosomal RNA sequences for phylogenetic analyses. Proc Natl Acad Sci US A 82, 6955 6959.

Larsen N., Olsen, G. J., Madak, B. L., McCaughey, M. J., Overbeek, R., Make, T. J., Marsh, T. L. \& Woese, C. R. (1993). The ribosomal database project. Nucleic Acids Res 21, 3021-3023.

Maltseva, O. V., Solyanikova, I. P., Golovleva, L. A., Schlömann, M. \& Knackmuss, H.-J. (1994). Dienelactone hydrolase from Rhodococcus erytbropolis 1CP: purification and properties. Arch Microbiol 162, 368-374.

Oren, A., Gurevich, P., Azachi, M. \& Henis, Y. (1992). Microbial degradation of pollutants at high salt concentration. Biodegradation 3, 387-398

Pankow, J. F., Johnson, R. L., Houck, J. E., Brillante, S. M. \& Bryan, W. J. (1984). Migration of chlorophenolic compounds at the 
chemical waste disposal site at Alkali Lake, Oregon. 1. Site description and ground-water flow. Ground Water 22, 593-601.

Perkins, E. J., Gordon, M. P., Caceres, O. \& Lurquin, P. F. (1990). Organization and sequence analysis of the 2,4-dichlorophenol hydroxylase and dichlorocatechol oxidative operons of plasmid pJP4. J Bacteriol 172, 2351-2359.

Sasser, M. \& Wichman, M. D. (1991). Identification of microorganisms through use of gas chromatography and high performance liquid chromatography. In Manual of Clinical Microbiology, pp. 11-118. Edited by W. J. Hausler, K. L. Herrmann, H. D. Isenberg \& H. J.Shadony. Washington, DC: American Society for Microbiology.

Schlömann, M., Pieper, D. H. \& Knackmuss, H.-J. (1990). Enzymes of haloaromatics degradation: Variations of Alcaligenes on a theme by Pseudomonas. In Pseudomonas: Biotransformation, Pathogenesis, and Evolving Biotechnology, pp. 185-196. Edited by S. Silver, A. M. Chakrabarty, B. Iglevsky \& S. Kaplan. Washington, DC: American Society for Microbiology.

Seibert V., Stadler-Fritzsche, K. \& Schlömann, M. (1993). Purification and characterization of maleylacetate reductase from Alcaligenes eutrophus JMP 134 (pJP4). J Bacteriol 175, 6745-6754.

Suwa, Y., Holben, W. E. \& Forney, L. J. (1994). Cloning of a novel
2,4-D catabolic gene isofunctional to $t f d A$ from Pseudomonas sp. TFD3. In Abstracts of the 94th General Meeting of the American Society for Microbiology. Washington, DC: American Society for Microbiology.

Tonso, N. L., Matheson, V. G. \& Holben, W. E. (1995). Polyphasic characterization of a suite of bacterial isolates capable of degrading 2,4-D. Microb Ecol 30, 1-22.

Vallaeys, T., Fulthorpe, R. R., Wright, A. M. \& Soulas, G. (1996). The metabolic pathway of 2,4-dichlophenoxyacetic acid degradation involves different families of $t f d A$ and $t f d B$ genes according to PCR-RFLP analysis. FEMS Microbiol Ecol (in press).

Vreeland, R. H., Litchfield, C. D., Martin, E. L. \& Elliot, E. (1980). Halomonas elongata, a new genus and species of extremely salttolerant bacteria. Int J Syst Bacteriol 30, 485-495.

Weisburg, W. G., Barns, S. M., Pelletier, D. A. \& Lane, D. J. (1991). 16S ribosomal DNA amplification for phylogenetic study. J Bacteriol 173, 697-703.

Wolin, E. A., Wolin, M. J. \& Wolfe, R. S. (1963). Formation of methane by bacterial extracts. $J$ Biol Chem 238, 2882-2886.

Received 12 September 1995; revised 22 December 1995; accepted 10 January 1996. 